\title{
The Impact of Marine Tourism Towards the Local Community at Pulau Pangkor, Perak
}

\author{
Firdaus Chek Sulaiman, Norajlin Jaini, \\ Ely Rouzee Jamaluddin, Nur Idzhainee Hashim \\ Centre of Studies for Park and Amenity Management, \\ Faculty of Architecture, Planning and Surveying, \\ Universiti Teknologi Mara, 40450 Shah Alam, Selangor, Malaysia \\ firdaus_879@yahoo.com
}

\begin{abstract}
Marine tourism is one of the main factors contributing to the growth of the tourism sector in Malaysia. Malaysia is among the countries that have assets of most beautiful islands with diverse marine life. It is attracting visitors to enjoy the beauty of the sea nature. The vibrant activity was an opportunity for local community to engage in the tourism sector. Thus, this study was conducted to determine the perceptions of local community towards the impact of tourism activities in Pulau Pangkor. The study involved 150 respondents among the local community that involved in the tourism sector.
\end{abstract}

Keywords: marine tourism, environmental sustainability, local tour business, local tour operators

eISSN 2398-4279 @ 2018. The Authors. Published for AMER ABRA cE-Bs by e-International Publishing House, Ltd., UK. This is an open access article under the CC BY-NC-ND license (http://creativecommons.org/licenses/bync-nd/4.0/). Peer-review under responsibility of AMER (Association of Malaysian Environment-Behaviour Researchers), ABRA (Association of Behavioural Researchers on Asians) and cE-Bs (Centre for EnvironmentBehaviour Studies), Faculty of Architecture, Planning \& Surveying, Universiti Teknologi MARA, Malaysia.

DOI: https://doi.org/10.21834/ajqol.v3i13.174 


\subsection{Introduction}

Marine tourism is a key global factor contributing to the growth of the tourism sector in Malaysia. The sector provides a primary source of income employment and wealth to the country and most importantly focus on the country's administration with the establishment of Ministry of Culture, Arts, and Tourism in 1987. It has been acclaimed that Malaysia offers aesthetic value, an outstandingly beautiful island in the world and rich biodiversity which provides beneficiary to the economic aspects of the local community development and the business industry. Pulau Pangkor was chosen as the study area since it is a major tourist attraction in Perak and is currently moving towards a world-class tourism centre. The growth of this industry brings impact towards the environment, social and cultural. However, these marine coastal areas are among the most threatened habitat in the world. These are due to over-exploitation on marine tourism activities, excessive admittance of tourists, unmonitored activities which give possible damage and impacts to the economic, socio-cultural, and environmental. Marine tourism activities can also cause loss of biodiversity in many ways more specifically, adverse impacts on the local community development. This study was conducted using questionnaire survey to identify the impacts of marine tourism towards local community. The respondents were chosen through a simple random sampling among the local community. The finding shows that marine tourism involving entrepreneurial activities has a high impact on the socio-economic development of the local population and moderate impact to the environment. Hence, the results of this study can serve as inputs to the Ministry of Tourism Malaysia and to the Perak State Government specifically in developing efficient and effective strategies to promote Pulau Pangkor with minimums effects.

\subsection{Study area}

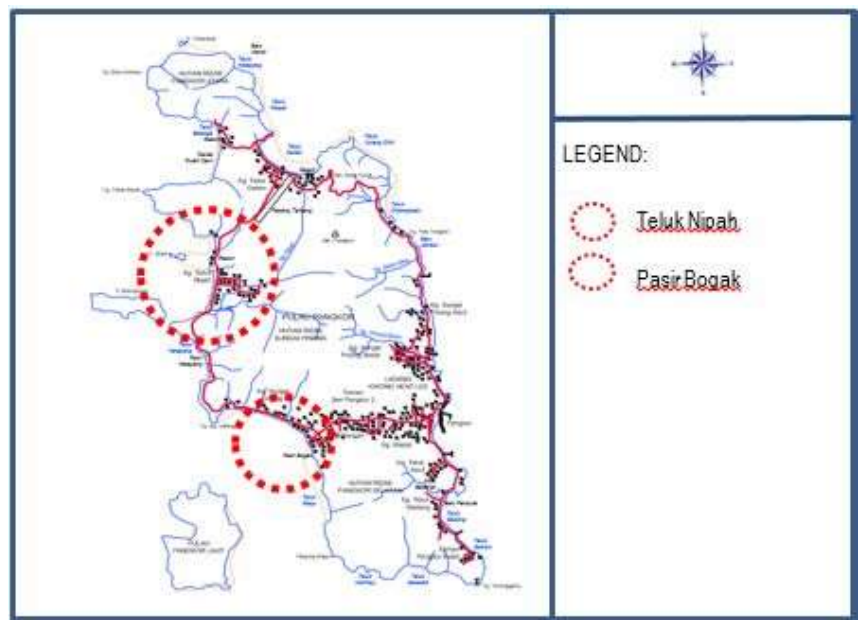

Fig. 1: Map of Pulau Pangkor, Perak 
This research was conducted in Pulau Pangkor specifically in Teluk Nipah and Pasir Bogak. It has been chosen as a survey location due to involvement of local community as the local tour operators.

\subsection{Literature Review}

\subsection{Marine Tourism}

According to Mohonk Agreement, (2001), described the marine tourism is closely related to sustainable tourism, which aims to reduce the logical impact and socio-cultural as well as providing economic benefits to local communities and host countries. Sustainable development is to meet the needs of the present generation without compromising the ability of future generations to respond to their needs. The involvement of the community is an integral part of a tourism development. It is important that every member of the community involved in the tourism development activities not only contribute to the development of tourism destinations, even indirect benefits to the local community. According to studies on 'The Impact of Tourism on Small Business Performance: Empirical Evidence from Malaysian Islands' by Pazim Othman and M. Mohd Rosli (2011), stated that Teluk Nipah, Coral Bay, and Pasir Bogak are some of the most attractive beaches available on the island. In previous tourism research have explored in detail the involvement of residents in tourism development. This is due to the local population is one of the stakeholders who play a major role in tourism development.

Marine based tourism businesses include ferry companies, marinas, cruise lines, and other form of water transportation. Therefore, transport services in Pulau Pangkor involving the tourism industry which bring tourist to move from one to another place. On the other hands, marine facilities included the equipment of water sport activities. Other services in marine tourism mainly in Pulau Pangkor were retail and handicraft, food services and accommodation.

\subsection{Community Development}

Tourism is increasingly seen as a key community tool, with the recognition of its economic contribution in bolstering stagnating economies and its ability to unify local tour operators residents (Fennell, 2003). At community levels, tourism offered opportunities for direct, indirect, and induced employment and income, spurring regional and local economic development (Aref, 2010; Coccossis, 2004). According to MSA Rasool (2011) state that poverty can happen because of working with low income, a high number of dependents, and unemployed. Tourism may have many different effects on the social and cultural aspects of life in a region or area, depending on the cultural and religious strengths of that region.

According to Oliver (2001), economy provides opportunities for every individual to improving the sustainability of their lives more comfortable. For example, get a better job, life status and so on. Income enables individuals to various types of expenses self and family. According to Lucy Ferguson (2006), in her research about 'Analyzing the Gender Dimensions 
of Tourism' state that how male control over household income had been diminished by the many opportunities for women to earn money in tourism communities. While the distribution of revenue used for equity and allocation of economic resources. Also, the work or the status of individual reward through ownership of dwellings, vehicles, clothing, food and etc.

\subsection{Result and Discussion}

\subsection{Background of Respondents}

The highest category of respondents was between the range of 18 to 25 years old which were 40 respondents $(26.7 \%)$. Followed by 26 to 30 years old with 30 respondents $(20 \%)$. The lowest categories were 36 to 40 years old with 22 respondents (14.7\%). This shows that in this research, more young people engage in marine tourism and providing services to tourists. The gender data shows two categories which are male and female with 92 respondents $(61.3 \%)$ and 58 respondents $(38.7 \%)$ respectively. Therefore, the results indicate that more male than female which is local tour operator involved in marine tourism activities in Pulau Pangkor. According to Lucy Ferguson (2009), in her research about 'Analysing the Gender Dimensions of Tourism' state that how male control over household income had been diminished by the many opportunities for women to earn money in tourism communities. Marital status data is also recorded in the survey data. The highest category is married about 89 respondents with $59.3 \%$, while the single status of 60 respondents equals to $40.0 \%$. The other items such divorce is only one person of the respondent with $0.7 \%$.

Another item that been recorded is in the occupation of respondents at Pulau Pangkor. Among the highest occupation is self-employment which is 124 respondents with $82.7 \%$. Followed by the private sector were by 19 respondent's equals to $12.7 \%$. Moreover, the lowest is government personnel were seven respondents with $4.7 \%$. In this study present that majority local operators who engage in self-employment and only focus on the tourism sector in Pulau Pangkor. Regarding the income of respondent, the highest income is RM1,001 to RM2,000 were 62 respondents $(41.3 \%)$. The intermediate category is below RM 1000 were record 60 respondents with $40 \%$, and RM2,001 to RM3,000 is 18 to $12 \%$. Moreover, lastly, the lowest category is RM 4001 and above by two respondents only by $1.3 \%$. According to the respondents, they could sustain this kind of income because the cost of living in rural areas that are not too high in Pulau Pangkor.

The race of the visitors shown that the highest was Malay, about 112 respondents or $74.7 \%$. Next item is Chinese; about 24 respondents are recorded or $16 \%$. The lowest race was Indian, about 14 respondents, $9.3 \%$. This means that more Malay engaged in marine tourism where these communities need to make a living other than fisheries. The highest rate that has been recorded for the research is secondary level with 86 respondents $(57.3 \%)$. The lowest is the small group for other item was recorded in this section; others define that they do not have any education level, about two respondents or $1.3 \%$. 


\subsection{Analysis Tour Operator Information}

Table 1 shows the result of tour operator information on the division of the length of business. The highest period of business was less than five years which were 53 respondents (35.3\%). For the duration of business between $10-14$ years and $16-19$ years were indicated $14 \%$ (21 respondents) for each duration. Only $11.4 \%$ (17 respondents) were involved for 20-25 years in tour business. Based on the study, the types of services involved by the local community were retail and handicraft, accommodation, transportation, marine facilities tour and food services.

Table 1: Data of Tour Operator Information

\begin{tabular}{lcc}
\hline Age of Business & Frequency & Percentage $(\%)$ \\
\hline $20-25$ years & 17 & 11.4 \\
$15-19$ years & 21 & 14.0 \\
$10-14$ years & 21 & 14.0 \\
Less than 5 years & 53 & 35.3 \\
Total & 150 & 100 \\
\hline
\end{tabular}

\subsection{Analysis for socio-cultural impact}

Table 2 shows the result of the influence of marine tourism towards the social impact. The result indicated that only increase English proficiency influenced the social of the community. It was obtained mean 4.03 which indicated agreed by the respondents. It is believed that the community has improved their English proficiency through the communication with foreign tourists. This had influenced the community to train themselves speaking in English. According to Sahazali, N., \& Choy, E. A. (2013) stated the social impact resulting from ecotourism activities in Seri Manjung analysis found an increased impact on the use of English. The arrival of foreign tourists has been able to improve English proficiency among the locals. Therefore, they need to learn to communicate in the English language.

Table 2: Social impact

\begin{tabular}{|c|c|c|c|c|c|c|c|c|c|c|c|}
\hline \multirow[t]{2}{*}{ Elements } & \multicolumn{2}{|c|}{$\begin{array}{l}\text { Strongly } \\
\text { Disagree }\end{array}$} & \multicolumn{2}{|c|}{ Disagree } & \multicolumn{2}{|c|}{ Neutral } & \multicolumn{2}{|c|}{ Agree } & \multicolumn{2}{|c|}{ Strongly agree } & \multirow[t]{2}{*}{ Mean } \\
\hline & Freg & $\%$ & Freg & $\%$ & Freg & $\%$ & Freq & $\%$ & Freq & $\%$ & \\
\hline Foreign Cultures & 7 & 4.7 & 12 & 8.0 & 67 & 44.7 & 54 & 33.3 & 14 & 9.3 & 3.35 \\
\hline Better Facilities & 6 & 4.0 & 13 & 8.7 & 39 & 26.0 & 67 & 44.7 & 25 & 16.7 & 3.61 \\
\hline $\begin{array}{l}\text { Crime and Social } \\
\text { Problems }\end{array}$ & 3 & 2.0 & 10 & 6.7 & 50 & 33.3 & 55 & 36.7 & 32 & 21.3 & 3.69 \\
\hline $\begin{array}{l}\text { Community's } \\
\text { Development }\end{array}$ & 6 & 4.0 & 1 & 0.7 & 31 & 20.7 & 88 & 58.7 & 24 & 16.0 & 3.82 \\
\hline $\begin{array}{l}\text { Increase English } \\
\text { proficiency }\end{array}$ & 7 & 4.7 & 1 & 0.7 & 20 & 13.3 & 74 & 49.3 & 48 & 32.0 & 4.03 \\
\hline
\end{tabular}

On the other hands, the other four elements were on the neutral scale. However, the three aspects (better facilities, crime and social problem, community development) shows the mean that inclined to be agreed (mean 3.50-3.99). Whereas, only the elements of foreign 
culture obtained the least mean (3.35) and slightly tend to be disagreed. The result proved that the marine tourism had only a minor influenced on social impact.

\subsection{Analysis for economic impact}

Table 3 shows the statement on how the marine tourism influenced the economic impact. Based on the result, there were four elements included in economic impact. The four elements obtained slightly similar mean which is in the range from 3.78 to 3.99 (Neutral). These indicated that the economic impact was not strongly influenced the local community. There were none of the elements attained mean more than 4.00 (Agree). However, all the mean for each item gained mean more than 3.50 which is tended to be Agree. It is believed that if there is some improvement on the economic opportunities, it will improve their economic impact. In general, tourism is generating the income to local community economy. Local community at Pulau Pangkor also contribute to marine tourism activities and increase the income indirectly through the arrival of tourist. Based David J. Telfer, Richard Sharpley, (2008), at the local level, the most significant economic benefit is income generation. Tourism provides an income for any individual or business that provides goods or services for tourists. This includes hotels, restaurants, bars, transport, and entertainment, etc. All the owners and employees of these businesses gain directly from the tourism industry.

Table 3: Economic impact

\begin{tabular}{|c|c|c|c|c|c|c|c|c|c|c|c|}
\hline \multirow[t]{2}{*}{ Elements } & \multicolumn{2}{|c|}{$\begin{array}{l}\text { Strongly } \\
\text { Disagree }\end{array}$} & \multicolumn{2}{|c|}{ Disagree } & \multicolumn{2}{|c|}{ Neutral } & \multicolumn{2}{|c|}{ Agree } & \multicolumn{2}{|c|}{ Strongly agree } & \multirow[t]{2}{*}{ Mean } \\
\hline & Freq & $\%$ & Freq & $\%$ & Freq & $\%$ & Freq & $\%$ & Freq & $\%$ & \\
\hline $\begin{array}{l}\text { Job Oppontunifies to } \\
\text { Local Communites }\end{array}$ & 8 & 5.3 & 2 & 1.3 & 27 & 18.0 & 80 & 53.3 & 33 & 22.0 & 3.85 \\
\hline & 10 & 6.7 & 2 & 3 & 34 & 22.7 & 69 & 46.0 & 35 & 23.3 & 3.78 \\
\hline Increase incomes & 3 & 2.0 & 3 & 2.0 & 36 & 24.0 & 58 & 38.7 & 50 & 33.3 & 3.99 \\
\hline $\begin{array}{l}\text { Decrease } \\
\text { Unemployment Rate }\end{array}$ & 6 & 4.0 & 1 & 0.7 & 42 & 28.0 & 68 & 45.3 & 33 & 22.0 & 3.81 \\
\hline
\end{tabular}

\subsection{Analysis Environment Impacts}

Table 4 shows about the influenced of marine tourism towards environmental impact. The elements of environmental impact included the pollution, maintenance of infrastructure and traffic congestions.

Table 4: Environmental impact

\begin{tabular}{|c|c|c|c|c|c|c|c|c|c|c|c|}
\hline \multirow[t]{2}{*}{ Elements } & \multicolumn{2}{|c|}{$\begin{array}{l}\text { Strongly } \\
\text { Disagree }\end{array}$} & \multicolumn{2}{|c|}{ Disagree } & \multicolumn{2}{|c|}{ Neutral } & \multicolumn{2}{|c|}{ Agree } & \multicolumn{2}{|c|}{ Strongly agree } & \multirow[t]{2}{*}{ Mean } \\
\hline & Freq & $\%$ & Freq & $\%$ & Freq & $\%$ & Freq & $\%$ & Freq & $\%$ & \\
\hline Pollution & 4 & 2.7 & 9 & 6.0 & 48 & 32.0 & 67 & 44.7 & 22 & 14.7 & 3.63 \\
\hline $\begin{array}{l}\text { Maintenance of } \\
\text { Infrastructure }\end{array}$ & 1 & 0.7 & 6 & 4.0 & 30 & 20.0 & 79 & 52.7 & 34 & 22.7 & 3.93 \\
\hline Traffic Congestion & 1 & 0.7 & 7 & 4.7 & 17 & 11.3 & 69 & 46.0 & 56 & 37.3 & 4.15 \\
\hline
\end{tabular}


The traffic congestion was the highest mean (4.15) gained in environmental impact. The mean scale shows on the agreed level. The arrival of tourists especially on weekends resulted in the area crowded and dense. Many respondents suggested that the government expand the roads in Pulau Pangkor due to the small and narrow roads. According to JA Ibrahim, N Abdul Razak, MZ Ahmad (2012) stated that the layout of the buildings that unorganized and create an uncomfortable environment and congestion, especially along the coastline. Tourist forced through the narrow spaces between buildings to get to the beach. On the other hands, pollution and maintenance of infrastructure indicated the mean 3.63 and 3.93 respectively which was fall on the neutral scale. However, the mean was inclined to be Agree which need some improvement on these matters.

\subsection{Conclusion}

Overall, the study found that marine tourism activities in Pulau Pangkor have some influenced on the social, economic and environment. The industry has supported the government in improving the growth of the economy. Regarding economic impacts have been identified marine tourism increased revenue to the local community. Also, many initiatives that can be run by local people for promoting marine tourism in Pulau Pangkor. Meanwhile, the local community proved that there were influenced on sociocultural, but the impact was at a minimum level. Sociocultural effects are as positive can improve English language skills while shaping their culture. There is still a lot more jobs and business opportunities that should be open to local communities to improve their economies. Similarly, another effort is to provide facilities and services to enhance the quality of the marine tourism product. Pulau Pangkor development will be advanced if the locals banded together to keep around and identify the impact that comes from the marine tourism.

\subsection{Acknowledgements}

We would like to thank the Centre of Studies Parks and Amenity Management, Faculty of Architecture, Planning and Surveying, UiTM Shah Alam, Selangor, Malaysia, Syazwana binti Jamaludin who had contributed in the data collection and all the respondents who kindly participated in the questionnaires survey.

\subsection{References}

JA Ibrahim, N Abdul Razak, MZ Ahmad (2012). The impact of tourism development on beach destination: Case study of Cenang Beach, Langkawi. Persidangan Kebangsaan Ekonomi Ke VII, 601-610. Retrieved from: www.ukm.my/fep/perkem/pdf/perkemVII/PKEM2012_2E2.pdf

Kaur, C. R. (2007). Ecotourism in Malaysia's Marine Parks: Principles, Issues and the Effects of "Green Washing" Practices. 5th Asia Pacific Ecotourism Conference 2007 (APeco 2007),2007(October).Keusahawanan, T. A., \& Sekitar, A. (2012). Jurnal Teknologi Full paper Pelancongan Marin : Impak Aktiviti Selam Skuba dan Snorkeling, 59, 57-63. 
Koens, J. F., Dieperink, C., \& Miranda, M. (2009). Ecotourism as a development strategy: Experiences from Costa Rica. Environment, Development and Sustainability, 11, 1225- 1237. http://doi.org/10.1007/s10668-009-9214-3

Kuponiyi, F. A. (2008). Community Power Structure: The Role of Local Leaders in Community Development Decision Making in Ajaawa, Oyo State, Nigeria. The Anthropologist, 10(4), 239-243.

Manaf, A., Saad, S., \& Hussain, M. Y. (2012). Isu keterancaman keselamatan perairan Mersing dan pulau-pulau di sekitarnya, 6(6), 49-58.

Mathieson, A. \& Wall, G. (1982), "Tourism: economic, physical and social impacts", Longman: Harlow, UK.

Medlik, 2003. Dictionary of Travel, Tourism and Hospitality. Butterworth-Heinemann, UK, ISBN: 0750656506

Mohammadi, M. (2010). Local People Perceptions toward Social, Economic and Environmental Impacts of Tourism in Kermanshah (Iran). Social Science, 6(11), 220-225.

Mohd, A., Ak, R., Suki, N. M., \& Dawood, M. M. (2014). Activity and Support Factors Influencing Increased Value Of Invertebrates In Ecotourism, 72-75.

Nguyen, Q.-H. (2007). Putting Community First: Tourism for Development in Doi Village, Central Vietnam. School of Social Science, Master of (November).

Orams, M. B. (2002). Marine ecotourism as a potential agent for sustainable development in Kaikoura, New Zealand. International Journal of Sustainable Development, 5(3), 338. http://doi.org/10.1504/IJSD.2002.003757

Othman, N., Mohamed, S., \& Aziz, F. K. (2012). Tourism activities and its impact on environmental sustainability in coastal areas. International Business Management, 6(6), 629-633. http://doi.org/10.3923/ibm.2012.629.633

Pakhriazad, H. ., Mohd. Hasmadi, I., Aida, H. M. ., \& Jusoff, K. (2014). Historical and Current Legislations of Taman Negara National Park Peninsular Malaysia. Journal of Politics and Law, 2(1), 44-49. http://doi.org/10.5539/jpl.v2n1p44

Pazim Othman and M. Mohd Rosli (2011) The Impact of Tourism on Small Business Performance: Empirical Evidence from Malaysian Islands, International Journal of Business and Social Science. Vol. 2 No. 1. Pages 11-21. Retrieved from: http://www.ijbssnet.com/journals/Vol._2_No._1\%3B_January_2011/2.pdf.

Phimmakong, K. (2011). Local perspective on Community Based Ecotourism : A Case Study in Ban Na in Phu Khao Khoay National Protected Area, Lao PDR.

Projek, L., \& Kumpulan, I. (2013). Laporan projek inovasi kumpulan kaizen 2013, (2030). Rahayu, I. (2014). Tourism Sea Activities that Cause Damages Towards Coral Reefs in Sembilan Islands, 1(April 2013), 22-24.

Ross, S., \& Wall, G. (1999). Ecotourism: Towards congruence between theory and practice. Tourism Management, 20(1), 123-132. http://doi.org/10.1016/S0261-5177 (98)00098-3

Sahazali, N., \& Choy, E. A. (2013). Ekopelancongan di Taman Paya Bakau , Seri Manjung , Perak : Persepsi penduduk terhadap impak pembangunan Development impact of Malaysian ecotourism as perceived by the local public : The case of Bakau, Seri Manjung, Perak, 3(3), 69-79.

Singh, S., Timothy, D. J., \& Dowling, R. K. (Eds.). (2003). Tourism in destination communities. Cambridge, USA: CABI publishing 
Talbot, L., \& Verrinder, G. (2005). Promoting Health: The Primary Health Care Approach (3 ed.): Elsevier, Churchill Livingstone, Australia. Gilchrist, A. (2004). The well-connected community: a networking approach to community development: Community Development Foundation (Great Britain), The Policy Press, UK

Tesoriero, F., \& Lfe, J. (2006). Community development: community -based alternatives in an age of globalisation: Pearson Education Australia.

Toro, B., \& Claiborne, P. (2010). Community Participation in Tourism Development and the Value of Social Capital Master of Science in Tourism and Hospitality Management Master

Tranel, M. J. (2000). Wilderness Management Planning in an Alaskan National Park : Last Chance to Do It Right? Wilderness, 5 .

United Nations. (2002). Sustainable Tourism, Environmental Protection and Natural Resource Management: Paradise on Earth? Growth, (February), 20-22.

Vuuren, C. Van, \& Slabbert, E. (2011). Travel Motivation and Behaviour of Tourists to a South African Resort. International Conference on Tourism and Management StudiesAlgarve 2011, I, 295-304. http://doi.org/http://tmstudies.net/index.php/ectms/article/view/196

Wang, H. (2009). Study on the Eco-tourism Environment Protection Based on the External Theory, 13-17.

Williams, C. C. (2004). Community Capacity Building: A Critical Evaluation of the Third Sector Approach. Review of Policy Research, 21(5), 729-733.

Zaei, M. E., \& Zaei, M. E. (2013). The Impacts of Tourism Industry on Host Community. European Journal of Tourism Hospitality and Research, 1(2) 